\title{
18. LONG-TERM OBSERVATIONS OF PRESSURE AND TEMPERATURE IN HOLE 948D, BARBADOS ACCRETIONARY PRISM ${ }^{1}$
}

\author{
J.-P. Foucher, ${ }^{2}$ P. Henry, ${ }^{3}$ and F. Harmegnies ${ }^{2}$
}

\begin{abstract}
In June-July 1994, during Ocean Drilling Program (ODP) Leg 156, Holes 948D and 949C were drilled 4 and 2 km landward, respectively, of the deformation front of the Barbados accretionary prism. The two holes were equipped with subseafloor monitoring instrumentation to determine the fluid pressure in the décollement, and the thermal structure of the sediments after drilling disturbances had dissipated, and to monitor any natural temporal variations, if present. Strings of temperature and pressure sensors were suspended from circulation obviation retrofit kit (CORK) boreseals in both holes. In December 1995, data collected for 18 months were recovered by American and French scientists onboard Nautile during the joint expedition ODPNaut. In this paper, we present the results from Hole 948D. The temperature data indicate conductive heat transfer with a constant heat flow of $85 \mathrm{~mW} / \mathrm{m}^{2}$ at this hole. There is no thermal indication of fluid movement along the décollement or vertically through the prism sediments. The pressure record demonstrates that Hole 948D was not properly sealed from the sea bottom. One interpretation of the pressure record is that the weight of the mud column in the borehole gradually equilibrated with the fluid pressure in the décollement. According to this interpretation, the décollement is inferred to be moderately overpressured at $2.2 \mathrm{MPa}$ above the hydrostatic pressure.
\end{abstract}

\section{INTRODUCTION}

Fluid-flow processes are a major tectonic agent in the growth of accretionary prisms. They determine the pore-fluid pressure and, thus, the effective pressure that controls the sediment deformation (von Huene and Lee, 1982). They are also responsible for large fluid geochemical fluxes in the prism sediments and through the seafloor (Kastner et al., 1991). Yet, our understanding of fluid-flow processes in accretionary prisms remains limited, in particular, because of a lack of field data to constrain physical models of fluid movement in the sediments. Experimental data are particularly needed to quantify fluid-flow processes along active faults (Screaton et al., 1995).

A key question is the nature of the fluid-flow processes along décollements. Décollements of accretionary prisms are generally thought to have high, near-lithostatic fluid pressures, which allow relative movement to occur at low shear stresses between the subducting sediments below them and the prism sediments above them (Hubbert and Rubbey, 1959). Fluids drained from the subducting sediments in the inner parts of prisms flow to their frontal parts along décollements (Le Pichon et al., 1993). In frontal parts of accretionary prisms, the overpressured fluids contained in the décollements and their overlying sediments are expelled to the seafloor along active faults acting as high-permeability conduits (Westbrook, 1991) or by pervasive flow through the sediments (Henry et al., 1996). Steady-state models of sediment dewatering predict a loss of fluids out of the toe of an accretionary prism, such as the Barbados accretionary complex, of a few cubic meters per year per meter along the strike of the prism (Le Pichon et al., 1990), while the total loss for the world subduction zones could reach $1.8 \mathrm{~km}^{3} \mathrm{yr}^{-1}$ (Moore and Vrolijk, 1992). Processes, steady-state or transient, through which this large release of fluid occurs in frontal parts of accretionary prisms remain poorly documented.

${ }^{1}$ Shipley, T.H., Ogawa, Y., Blum, P., and Bahr, J.M. (Eds.), 1997. Proc. ODP, Sci. Results, 156: College Station, TX (Ocean Drilling Program).

${ }^{2}$ Département de Géosciences Marines, Centre IFREMER de Brest, BP 70, 29280 Plouzané Cédex, France. jfoucher@ifremer.fr

${ }^{3}$ Laboratoire de Géologie, Ecole Normale Supérieure, 24 rue Lhomond, 75231 Paris Cédex 05, France.
An ambitious borehole monitoring experiment was undertaken during Ocean Drilling Program (ODP) Leg 156 (June-July 1994) in the frontal part of the Barbados accretionary complex, to collect physical and chemical data, which is critical for a better understanding of the processes of fluid circulation in the décollement and through the prism sediments. Two holes, Holes 948D and 949C, were drilled on the prism approximately $2 \mathrm{~km}$ and $4 \mathrm{~km}$ landward of the deformation front (see Figure 1 in Becker et al., Chapter 19, this volume). They were equipped with subseafloor monitoring instruments to determine the fluid pressure in the décollement, and the thermal structure of the sediments after drilling disturbances had dissipated, and to monitor any natural temporal variations, if present. In addition, a fluid sampler was deployed in Hole 949C.

A marked distinction between the three sites drilled during Leg 156 is in the seismic signature of the décollement. At Sites 948 and 949, the seismic reflection at the décollement has a normal, positive polarity, whereas, it has a negative polarity at Site 947 (Shipley et al., 1994). The negative polarity at Hole $949 \mathrm{C}$ could indicate a lower density of the sediments in the décollement, possibly because the fault zone became dilated as a consequence of a higher fluid pressure. Collecting direct measurements of the fluid pressures in the décollements at Holes 948D and 949C, in relation to their seismic signatures, was therefore a specific objective of the monitoring experiment undertaken on Leg 156.

In December 1995, 11/2 yr after the deployment of the monitoring instruments on Leg 156, French and American scientists conducted the joint ODPNaut expedition and successfully recovered the data recorded in the two holes since deployment, using the submersible Nautile. We report in this paper the results from Hole 948D. A companion paper by Becker et al. (Chapter 19, this volume) describes the results from Hole 949C.

\section{METHODS: CONFIGURATION OF THE EXPERIMENT IN HOLE 948D}

A French designed (IFREMER) string comprising 20 sensor modules, 17 with two temperature sensors (redundancy wanted to eliminate effects of potential failure of individual sensors and as a way to 
check the accuracy of temperature measurements) and three with one pressure and one temperature sensor (Fig. 1; Table 1), was suspended in Hole 948D from a circulation obviation retrofit kit (CORK; Davis et al., 1992) boreseal. This string uses two serial lines to communicate digitally between the sensors and the data logger, allowing for a larger number of sensors to be connected than in previous CORK experiments.

The sensor string was deployed with the deepest sensor module, measuring both temperature and pressure, positioned in the hole at $508.8 \mathrm{~m}$ below seafloor ( $\mathrm{mbsf}$ ). The depth interval of the zone of décollement at Hole 948C has been defined, on the basis of observations of a scaly fabric and stratal disruptions, between 498 and 529 mbsf, with a sharp top boundary and a gradational bottom (Shipboard Scientific Party, 1995). Hole 948D is located 200 m south of Hole 948C. Seismic data indicate that the décollement in Hole 948D is slightly shallower than at Hole 948C. Accounting for this depth uncertainty, the casing in Hole 948D was perforated and screened between 480.7 and 522.6 mbsf. Taking this depth interval as that of the zone of décollement at Hole 948D, one infers that three depths of measurement of temperature and one of pressure are within the décollement at this hole. In addition, a dense array of sensors, including six temperature sensors between 438.8 and $478.8 \mathrm{mbsf}$, were deployed on the upper side of the décollement. These temperature sensors and those in the décollement were intended to detect any thermal effects associated with possible transient flows of warm fluids along the décollement. Unfortunately, the hole was not deep enough to allow emplacement of sensors in the subducting sediments beneath the décollement.

The CORK at the top of the hole is designed to prevent fluids from passing into the formation from the seafloor or out of the formation to the seafloor, via the drill hole. It also allows the fluid pressure in the hole beneath the seal to equilibrate with that within the formation spanned by the perforated and screened casing. The CORK was properly seated at Hole 948D but could not be latched, leaving the weight of the CORK to hold the seal in place. Furthermore, a serious complication in the analysis of the borehole developed from the use of heavy mud to prevent sediment inflow from the bottom of the casing prior to deployment of the CORK sensor string. The mud was barite, mixed with bentonite, with a density of $1.66 \mathrm{Mg} / \mathrm{m}^{3}$.

The string uses platinum resistance-temperature devices (nominally $1000 \Omega$ at $0^{\circ} \mathrm{C}$ ). Accuracy of measurements is $0.1^{\circ} \mathrm{C}$. All sensors were calibrated before (May 1994) and after (May 1996) the experiment. Inferred drifts over the time interval between the two calibrations were less than $0.1^{\circ} \mathrm{C}$, for 18 sensors out of the 20 used. The two temperature sensors with larger drifts, both of about $0.3^{\circ} \mathrm{C}$, are those in the mixed temperature-pressure sensor modules at 478.8 and 508.8 mbsf. Temperatures presented in this report are all based on the calibration data of May 1994.

Pressure measurements were made with PaineR pressure gauges. They were calibrated for pressures ranging from 0 to $80 \mathrm{MPa}$, at $10^{\circ} \mathrm{C}$ temperature intervals from $0^{\circ} \mathrm{C}$ to $60^{\circ} \mathrm{C}$. When subject to a full calibration cycle (0-80 MPa), gauges have a slight hysteresis, with a deviation of the measured values from the mean value of less than 0.5 bar $\left(10^{5} \mathrm{~Pa}\right)$. Calibrations made before and after the experiment indicate stable responses, with drifts of less than 0.7 bar $\left(10^{5} \mathrm{~Pa}\right)$.

\section{RESULTS \\ Temperatures}

\section{Temperature Record}

Temperature curves (Fig. 2) show a smooth return to thermal equilibrium at all 20 depths of measurement in the first 2-3 months of the recording period (Fig. 2). Since the end of this initial period, temperatures remained nearly constant to the end of the experiment.

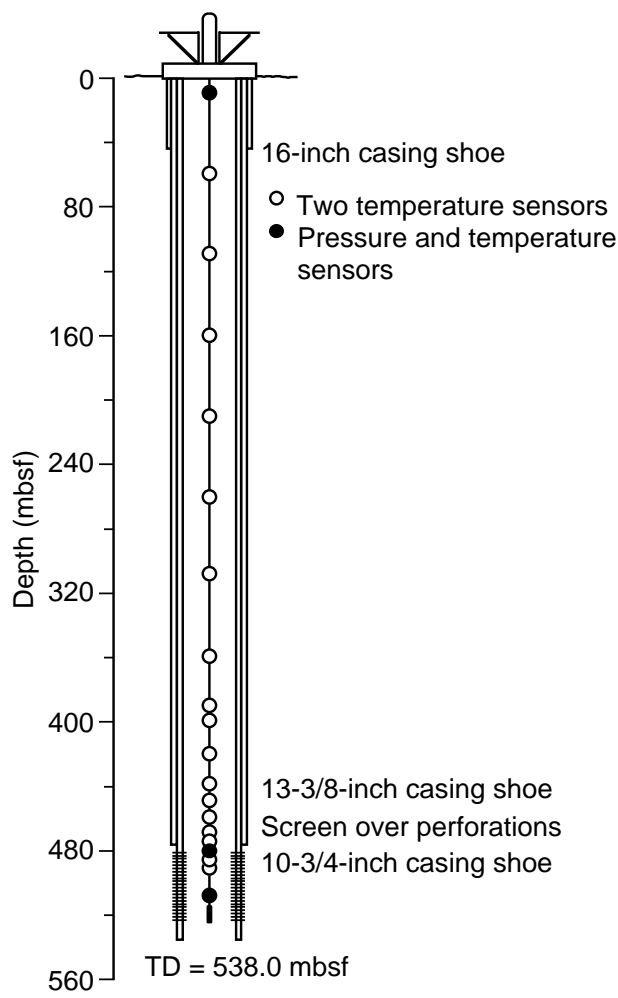

Figure 1. Configuration of the CORK, sensor string, casing, and screen in Hole 948D.

In the initial period, however, significant fluctuations, up to $1^{\circ} \mathrm{C}$ in amplitude, were recorded at several depths, over time scales of a few hours to a few days. These fluctuations were mainly observed at sensors located in the upper half section of the hole, and, as shown by Figure 2, the length of the initial period of the experiment during which these fluctuations occur is variable and tends to decrease with depth. The fluctuations are well illustrated by the temperature curve at $108.5 \mathrm{mbsf}$. The origin of these fluctuations is not known. One suggested explanation is the presence of mud movements in the hole.

The thermal recovery is longer for the sensors at or near the décollement (i.e., downhole the sensor at $468 \mathrm{mbsf}$ ) than for shallower sensors, with the exception of the deepest sensor at $508.8 \mathrm{mbsf}$. One interpretation for the thermal disturbance is because drilling penetrated the sediments around the hole more deeply at those particular depths with a longer thermal recovery. One would expect this to happen if the drilling fluid or even the heavy mud used in the hole invaded the upper part of the décollement fault zone and the sediments immediately above it. Figure 3 illustrates the linearity of the temperature profile with depth, including the depth interval near and across the décollement. The mean temperature gradient from the sea bottom to $508.8 \mathrm{mbsf}$ is $72^{\circ} \mathrm{C} / \mathrm{km}$, a value close to the mean gradient of $66^{\circ} \mathrm{C} / \mathrm{km}$ calculated from the three deep downhole water sampler, temperature and pressure probe (WSTP) measurements from Hole 948C over the depth interval from 247.1 to $420.5 \mathrm{mbsf}$.

\section{Sediment Thermal Conductivity and Heat Flow}

The conductive heat flow at a given depth is defined as the product of the temperature gradient and the thermal conductivity. Thermal conductivity is routinely measured by ODP on recovered sediment cores. Core recovery at Site 948 was limited to near the mud line and in the vicinity of the décollement. Thus, core measurements of thermal conductivity available from Site 948 alone were insuffi- 
Table 1. Configuration of the IFREMER sensor string deployed in Hole 948D, with final (December 1995) temperatures, initial (June 1994) and final (December 1995) pressures recorded.

\begin{tabular}{rrrrrrr}
\hline & & \multicolumn{2}{c}{ Measured temperatures $\left({ }^{\circ} \mathrm{C}\right)$} & Initial & Final \\
\cline { 3 - 4 } $\begin{array}{c}\text { Depth } \\
\text { (mbsf) }\end{array}$ & $\begin{array}{c}\text { Component } \\
\text { type }\end{array}$ & Final T1 & Final T2 & $\begin{array}{c}\text { Final T } \\
\text { mean }\end{array}$ & $\begin{array}{c}\text { pressure } \\
(.1 \mathrm{MPa})\end{array}$ & $\begin{array}{c}\text { pressure } \\
(.1 \mathrm{MPa})\end{array}$ \\
\hline 0 & & & & 2.1 & & \\
8.4 & TP & 5.07 & & 5.07 & 503.8 & 503.2 \\
58.5 & TT & 7.20 & 7.27 & 7.23 & & \\
108.5 & TT & 11.50 & 11.53 & 11.52 & & \\
158.6 & TT & 15.40 & 15.46 & 15.43 & & \\
208.6 & TT & 19.11 & 19.13 & 19.12 & & \\
258.7 & TT & 22.32 & 22.36 & 22.34 & & \\
308.8 & TT & 26.23 & 26.34 & 26.28 & & \\
358.8 & TT & 29.58 & 29.56 & 29.57 & & \\
388.8 & TT & 31.64 & 31.70 & 31.67 & & \\
398.8 & TT & 32.07 & 32.10 & 32.08 & & \\
418.8 & TT & 33.77 & 33.78 & 33.78 & & \\
438.8 & TT & 35.53 & 35.55 & 35.54 & & \\
448.8 & TT & 35.68 & 35.71 & 35.69 & & \\
458.8 & TT & 36.58 & 36.60 & 36.59 & & \\
468.8 & TT & 37.33 & 37.35 & 37.34 & & \\
473.7 & TT & 37.58 & 37.56 & 37.57 & & \\
478.8 & TP & 37.75 & & 37.75 & 583.2 & 570.2 \\
483.8 & TT & 38.38 & 38.37 & 38.38 & & \\
488.7 & TT & 38.73 & 38.78 & 38.75 & \multirow{2}{*}{574.6} \\
508.8 & TP & 40.39 & & 40.39 & 586.5 & \\
513.8 & SB & & & & & \\
\hline
\end{tabular}

Note: $\mathrm{TP}=$ one temperature and one pressure sensor, $\mathrm{TT}=$ two temperature sensors, and $\mathrm{SB}=$ sinking bar.

cient to estimate thermal conductivity throughout the depth range of the temperature measurements in Hole 948D, from the seafloor to the décollement. We used thermal conductivity data from Site 671, drilled on Leg 110, to complement the limited set of data available from Site 948. Sites 671 and 948 are less than $0.1 \mathrm{~km}$ distant from each other. However, a plot of thermal conductivity with depth shows that the thermal conductivity values from Site 671 are systematically higher than those from Site 948 for the entire depth range (Fig. 4). We suggest that the discrepancy is because the needle probe used for conductivity measurements during Leg 110 was not accurately calibrated. On Leg 156, three different standards were used for calibration and a linear correction was applied (Shipboard Scientific Party, 1995). Only one standard was used on Leg 110, and a constant factor correction was applied (Shipboard Scientific Party, 1989). We chose to correct the data from Leg 110 by applying a linear correction, to make the mean conductivity values from data collected on the two legs the same over the depth intervals $0-10 \mathrm{mbsf}(1.02 \mathrm{~W} /[\mathrm{m} \cdot \mathrm{K}])$, 420-500 $\mathrm{mbsf}(1.15 \mathrm{~W} /[\mathrm{m} \cdot \mathrm{K}])$, and 540-600 $\mathrm{mbsf}(1.17 \mathrm{~W} /[\mathrm{m} \cdot \mathrm{K}])$. The corrected conductivities for Leg 110, kcorr $_{110}$, are:

$$
\mathrm{kcorr}_{110}=0.6203 \mathrm{k}_{110}+0.3538 \text {, }
$$

where $\mathrm{K}_{110}$ are uncorrected conductivities from Site 671 (all values in $\mathrm{W} /[\mathrm{m} \cdot \mathrm{K}])$.

A mean heat-flow value is determined at Site 948 as the slope of the temperature plotted against the cumulative thermal resistance $\mathrm{R}(\mathrm{z})$ (Bullard, 1939), defined at a depth $\mathrm{z}$ as:

$$
\mathrm{R}(\mathrm{z})=\int_{0}^{z} 1 / k(z) d z
$$

Apart from a significant departure at $8.4 \mathrm{mbsf}$, temperature increases linearly with thermal resistance, indicating a constant conductive heat flow of $85 \mathrm{~mW} / \mathrm{m}^{2}$ (Fig. 5) This value is fairly coherent with surface heat-flow determinations in the area (Foucher et al., 1990).

\section{Implications}

The constant heat flow with depth indicates that the thermal effects of fluid flow were not detected in Hole 948D. Simple calcula- tions with a one-dimensional Darcian advection model (Bredehoeft and Papadopulos, 1965) and with the constraint that observed temperatures are not allowed to depart from predicted temperatures by more than $1{ }^{\circ} \mathrm{C}$, indicate that vertical flow rates should be less than about $0.005 \mathrm{~m} / \mathrm{yr}$. Also, the constant heat flow across the décollement implies that the horizontal flow rates along it do not exceed values of the order of $10 \mathrm{~m}^{3} / \mathrm{yr}$ per meter along strike of the subduction zone. This estimate is at least ten times smaller than initially proposed by Fisher and Hounslow (1990) and Foucher et al (1990).

Moreover, the characteristic time for thermal relaxation following circulation of warm fluid in the décollement is given by $\tau=\mathrm{d}^{2} / 4 \kappa$, where $\mathrm{d}$ is the distance from décollement and $\kappa$ is thermal diffusivity. Taking $\mathrm{d}=500 \mathrm{~m}$ (depth of décollement) and $\kappa=10-15 \mathrm{~m}^{2} / \mathrm{yr}, \tau$ is about $5000 \mathrm{yr}$. We conclude that no thermally detectable flow along the décollement occurred during the last $5000 \mathrm{yr}$.

\section{Pressures}

\section{Pressure Record}

Pressure was measured at $8.4 \mathrm{mbsf}$, below the CORK, at 478.8 mbsf, immediately above the décollement, and at $508.8 \mathrm{mbsf}$ in the décollement (Fig. 1; Table 1). The pressure records at 478.8 and 508.8 mbsf (Fig. 6) display similar decay for the first month of the experiment. At the end of this first phase (late July), the decrease accelerated abruptly at $507.9 \mathrm{mbsf}$; whereas, it slowed down considerably at $478.8 \mathrm{mbsf}$. The pressure at $478.8 \mathrm{mbsf}$ even exceeded that at $508.8 \mathrm{mbsf}$ from early August to late October 1994. The pressure at $508.8 \mathrm{mbsf}$ had virtually reached equilibrium in October 1994, only four months after the string was deployed. In contrast, the pressure at 478.8 mbsf continued to decrease significantly until the final measurements in December 1995. The decay was of five bars $\left(10^{5} \mathrm{~Pa}\right)$ from October 1994 to December 1995.

The pressure record at 8.4 mbsf indicates a small decay of $\sim 0.6$ bar $\left(10^{5} \mathrm{~Pa}\right)$ over the first five days of the experiment. Following this decay, pressure remains constant to the end of the experiment. There was no pressure change when Nautile opened the valve of the CORK during the ODPNaut cruise in December 1995. This demonstrates that the pressure measured over the total time of the experiment, except perhaps for the first five days of the experiment, was the hydrostatic pressure. Even for the first five days, the pressure decay can be accounted for by a gradual transition from a mud hydrostatic pressure 


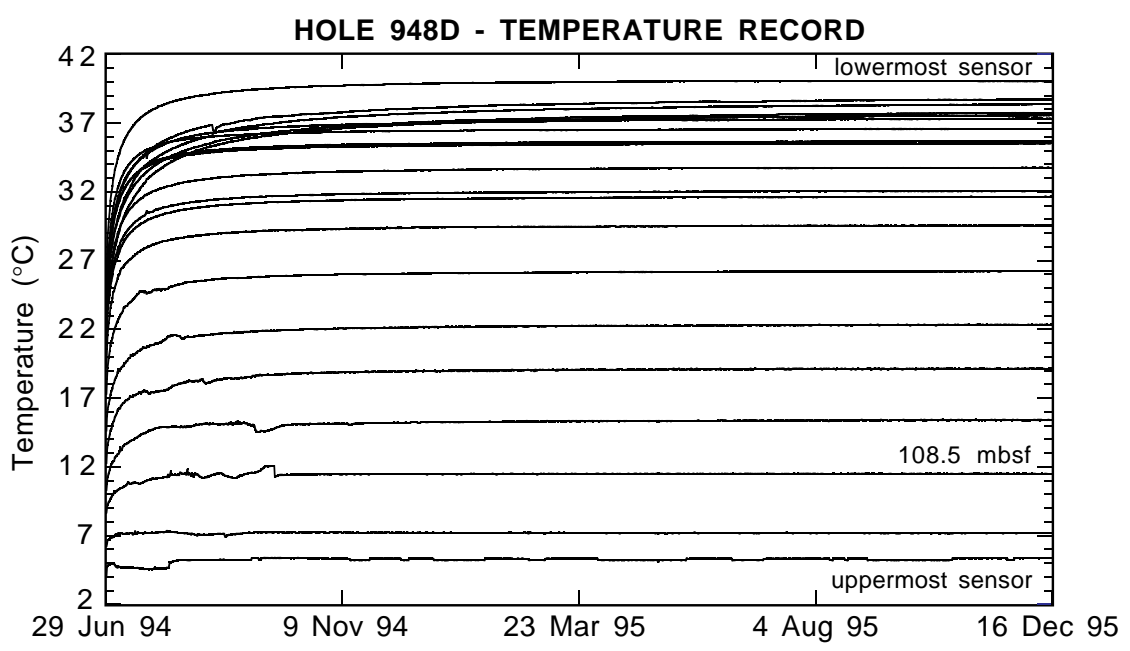

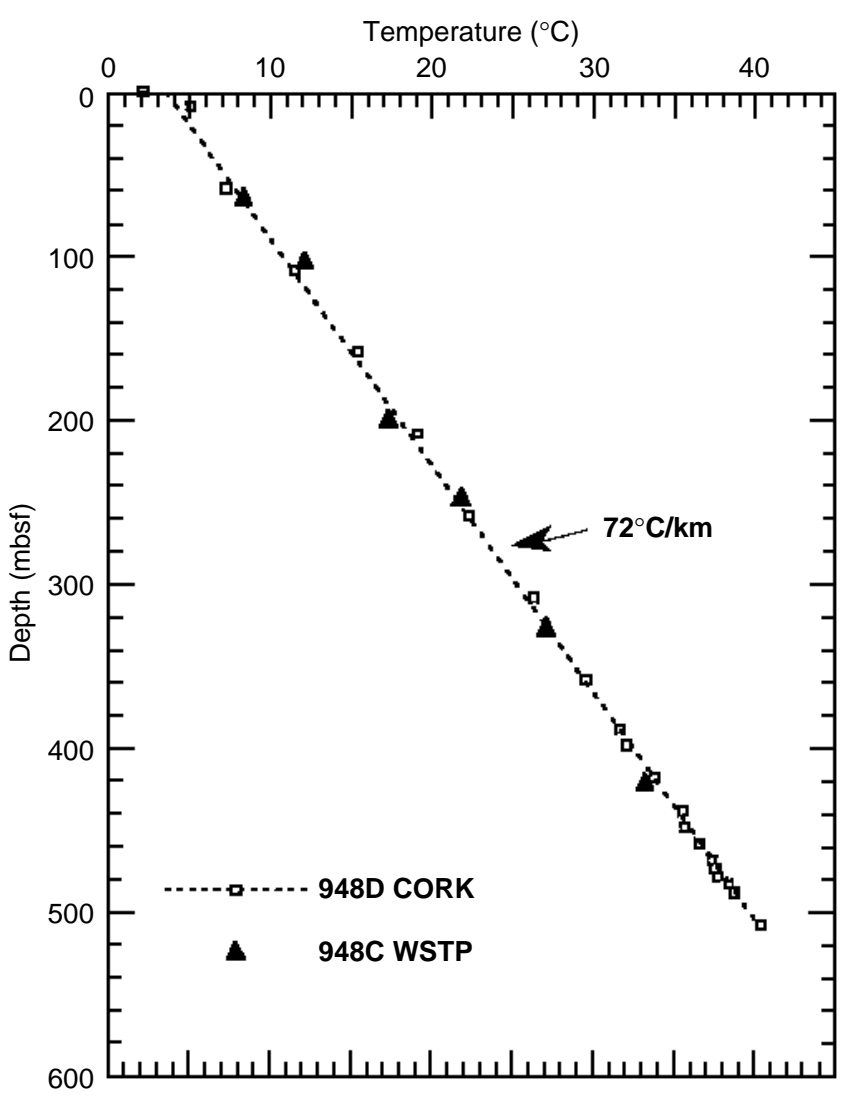

Figure 3. Downhole profile of final (December 1995) temperatures recorded at Hole 948D. Also shown are the WSTP temperatures measured on Leg 156. Dashed line is the profile calculated from a linear regression, with a slope (mean temperature gradient) of $72^{\circ} \mathrm{C} / \mathrm{km}$.

gradient to a seawater hydrostatic pressure gradient. One would expect this to happen if the hole was initially filled up to its top with heavy mud and if the mud in the uppermost section of the hole progressively moved down the hole, leaving room to a fluid with a smaller density, progressively approaching that of seawater.

The accuracy of the pressure measurements was not high enough to detect tidal effects.

\section{Thermal Conductivity (W/(m.K)) ODP Sites 671 and 948}

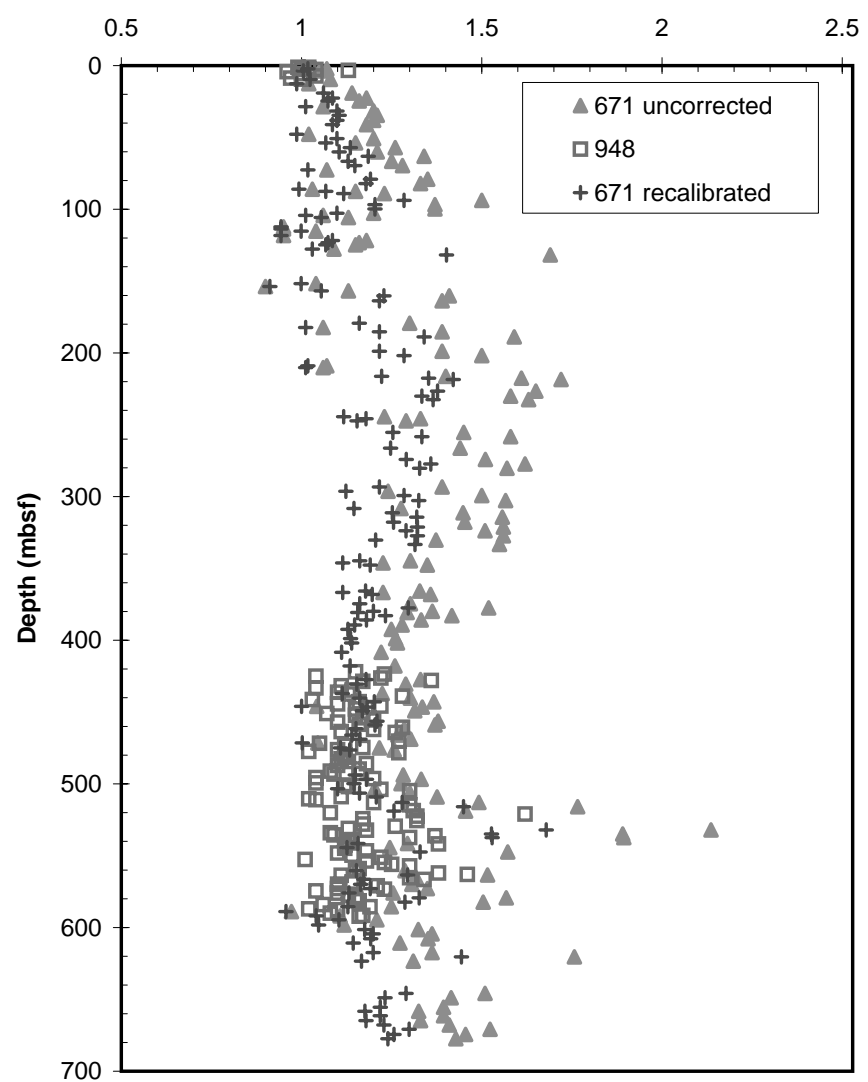

Figure 4. Thermal conductivities at Sites 671 and 948.

\section{Implications}

Because it is very unlikely that the hole, if properly sealed, could stay at hydrostatic pressure over the total time of the experiment, the flat pressure record at 8.4 mbsf suggests that the hole was leaking, probably from the very deployment of the string of sensors. 


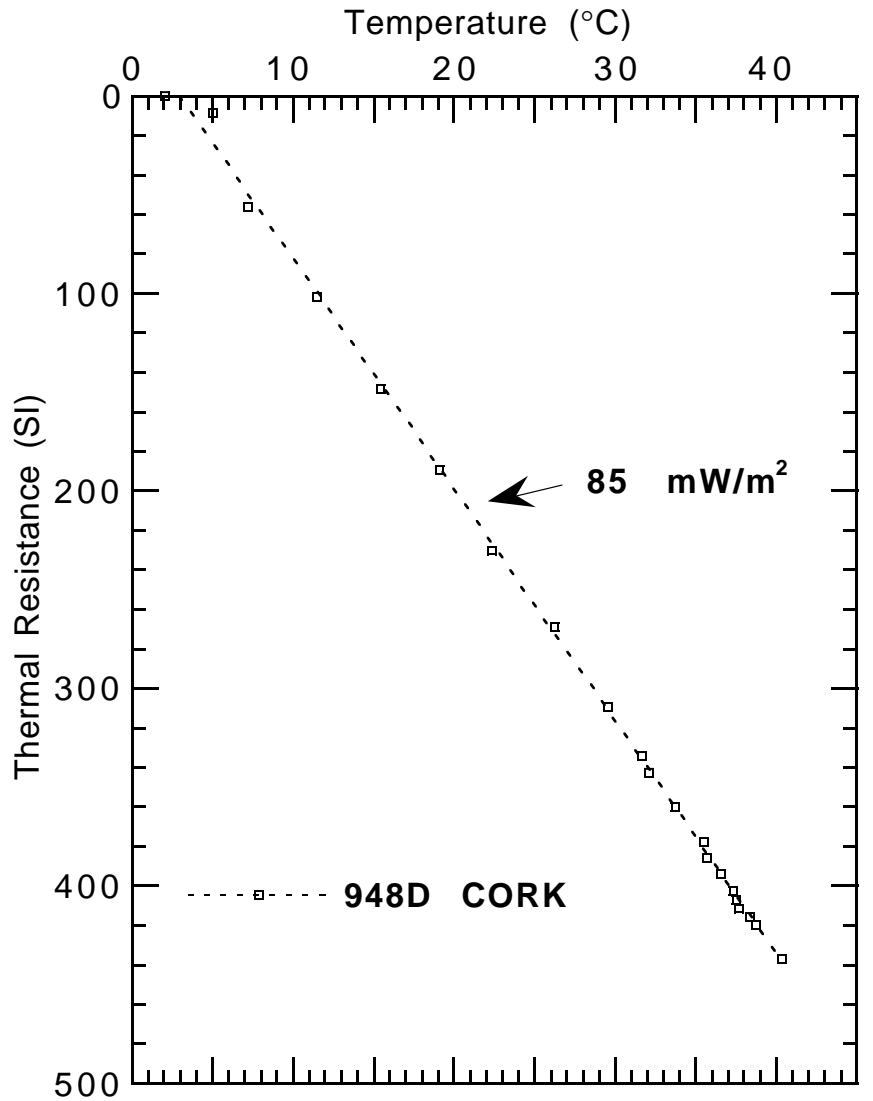

Figure 5. Final (December 1995) temperatures plotted as a function of thermal resistance at Hole 948D. Dashed line is the profile calculated from a linear regression. The slope gives a mean heat flow of $85 \mathrm{~mW} / \mathrm{m}^{2}$. SI $=\mathrm{m}^{2} \cdot \mathrm{K} / \mathrm{W}$.

The pressure decay curves at 478.8 and 508.8 mbsf are complex and cannot be explained by equilibration with a simple aquifer. We will limit ourselves in this preliminary presentation to examine simple interpretations of the initial and final values of the pressures measured at these two depths.

We think that the high initial pressure values at 478.8 and 508.8 mbsf were simply caused by the weight of the mud column in the hole. For a mud density of $1.66 \mathrm{Mg} / \mathrm{m}^{3}$, and assuming that the hole was initially filled up with mud, the calculated pressures at 478.8 and $508.8 \mathrm{mbsf}$ are 580.3 and 585.1 bars (58.0 and $58.5 \mathrm{MPa}$ ), respectively. These values are close to the measured pressures of 583.2 and 586.5 bars $(58.3$ and $58.6 \mathrm{MPa})$. Taking the mud density slightly higher at $1.7 \mathrm{Mg} / \mathrm{m}^{3}$ instead of $1.66 \mathrm{Mg} / \mathrm{m}^{3}$, would account for the small discrepancy.

Conversely, we interpret the final pressure values of 570.2 and 574.6 bars $(57.0$ and $57.5 \mathrm{MPa})$ as an indication that a large volume of mud had left the inner casing at the end of the experiment. The lost volume of mud would be about $15 \mathrm{~m}^{3}$. The lost mud could have flowed into the décollement or the casing annulus.

A steady-state pressure of 574.6 bars $(57.5 \mathrm{MPa})$ was reached at 508.8 mbsf. It may represent either an upper bound to the pressure in the décollement because the mud weight is apparently sufficiently large to compensate for the formation fluid pressure, or the minimum total stress $\sigma 3$, if the height of the mud in the hole reflects the threshold for mud injection into the décollement by hydrofracturing.

If the steady-state pressure is interpreted in terms of fluid pressure in the décollement, the pressure value in excess of hydrostatic pressure is $2.2 \mathrm{MPa}$ (with water density at $1.030 \mathrm{Mg} / \mathrm{m}^{3}$; Fig. 7). This excess fluid pressure of 2.2 MPa coincides with the lower bound from the packer tests performed on board (Shipboard Scientific Party, 1995). As the lithostatic pressure at the same depth is estimated at 9.1 $\mathrm{MPa}$ from the logging-while-drilling (LWD) gamma densitometry data from Hole $948 \mathrm{~A}$, the pore-pressure ratio is $\lambda=\left(\mathrm{P}_{\mathrm{f}}-\mathrm{P}_{\text {seafloor }}\right) /\left(\mathrm{P}_{\text {lith }}-\right.$ $\left.\mathrm{P}_{\text {seafloor }}\right)=0.8$ and the excess fluid-pressure ratio is $\lambda^{\prime}=\left(\mathrm{P}_{\mathrm{f}}-\mathrm{P}_{\text {hydro }}\right) /$ $\left(\mathrm{P}_{\text {lith }}-\mathrm{P}_{\text {hydro }}\right)=0.53$.

The alternative interpretation of the mud pressure in terms of minimum effective stress would imply that $\sigma 3$ is subhorizontal. An analysis of the anisotropy of magnetic susceptibility on core samples recovered from the lower part of the décollement and the sediment below it suggests that there was no significant compressive horizontal deformation in the studied core samples (Housen, Chapter 6, this volume) and provides support to the hypothesis that $\sigma 3$ is subhorizontal at least in the lower part of the décollement.

\section{CONCLUSIONS}

We have not found any thermal indication of fluid flow along the décollement for the last $5000 \mathrm{yr}$. This conclusion is consistent with the suggestion from an analysis of the chloride concentration profile with depth at Hole 948C that the latest fluid-flow pulse in the décollement occurred at least $60 \mathrm{ka}$ (Shipboard Scientific Party, 1995). We also showed that the mode of heat dissipation through the frontal part of the prism is conductive with a constant heat flow of $85 \mathrm{~mW} / \mathrm{m}^{2}$. This value is about $30 \mathrm{~mW} / \mathrm{m}^{2}$ higher than the normal heat flow of 55 $\mathrm{mW} / \mathrm{m}^{2}$ expected for an oceanic basin $80-85 \mathrm{Ma}$ (Langseth et al., 1988) The high heat flow was previously interpreted by Foucher et al. (1990) in terms of conductive heating from a hot décollement. The temperature data from the monitoring experiment at Hole 948D and those from the experiment at Hole 949C (Becker et al., Chapter 19, this volume) do not support this interpretation. They instead demonstrate that the origin of the high heat flow has to be found at a greater depth than that of the décollement.

A second result of the monitoring experiment at Hole 948D is that a steady-state pressure of 574.6 bars $(57.5 \mathrm{MPa})$ was measured at $508.8 \mathrm{mbsf}$ in the perforated casing section of the hole. If this pressure represents the fluid pressure in the décollement, the décollement is moderately overpressured at $2.2 \mathrm{MPa}$ above the hydrostatic pressure (i.e., about half-way between the hydrostatic pressure and the lithostatic pressure). However, this $2.2 \mathrm{MPa}$ value is considerably higher than the 1.0 MPa overpressure measured at Hole 949C (Becker et al., Chapter 19, this volume). Thus, the inferred overpressures at Holes 948D and 949C tend to verify the concept that a positive polarity seismic reflection at the décollement results from a simple density increase with depth through the décollement; whereas, a negative polarity seismic reflection results from a dilatant fault zone interval maintained by pore-water overpressure (Shipley et al., 1994). At Site 948, the void-ratio profile (derived from the density profile) was converted to an effective stress profile using the results of consolidation tests, which allowed researchers to predict a fluid-pressure profile (Moore et al., 1995). The calculated fluid pressure rises to $90 \%$ of the lithostatic pressure in the lower part of the prism. It becomes even closer to the lithostatic pressure in intervals in the décollement. The $2.2 \mathrm{MPa}$ overpressure that occurred in the décollement at Hole 948D appears to be significantly lower than the estimate by Moore et al. (1995).

\section{ACKNOWLEDGMENTS}

The monitoring experiment in Hole 948D would not have been possible without the invaluable technical support of the ODP drilling engineers, particularly Tom Pettigrew, and of the IFREMER engineering group, and particularly J. Crozon, J. Dupont, L. Floury, N. Lanteri, and Y. Le Guen. We are grateful to all of them. We also thank the entire scientific party of Leg 156, particularly the co-chief 


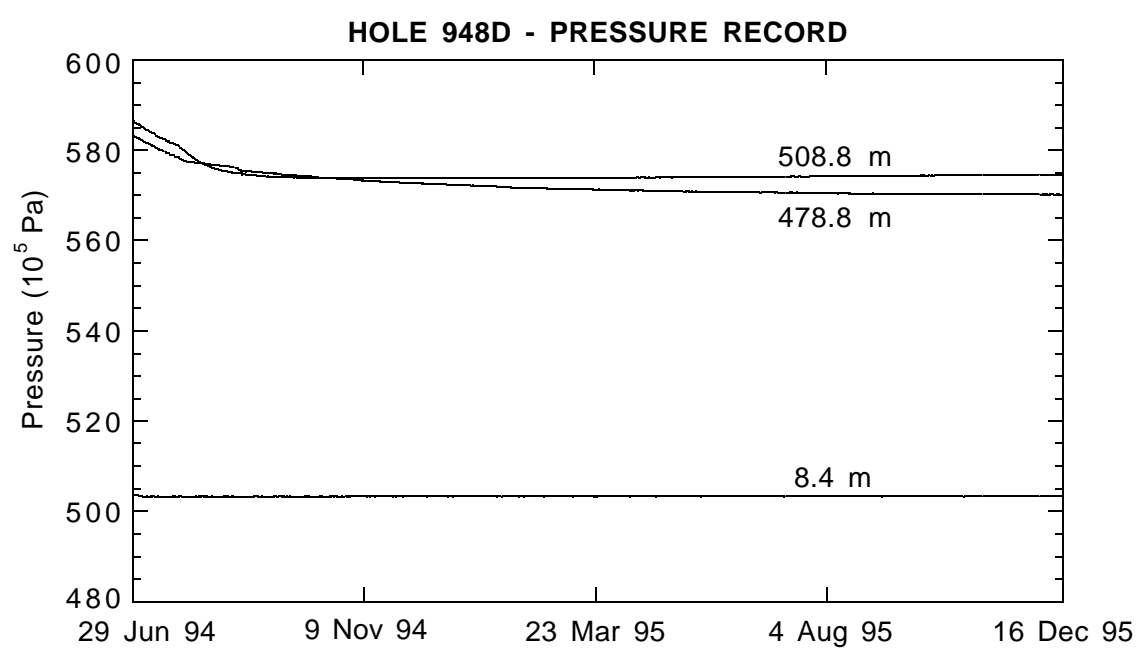

scientists, Y. Ogawa and T. Shipley, for their support of the time and resources required to deploy the two CORK experiments. We thank the Captains and crews of the JOIDES Resolution and Nadir, as well as the pilots of the submersible Nautile. Financial support was provided by the Ocean Drilling Program, ODP/France, IFREMER, and ENS Paris. The manuscript was improved by the review of Seiichi Nagihara.

\section{REFERENCES}

Bredehoeft, J.D., and Papadopulos, I.S., 1965. Rates of vertical groundwater movement estimated from the earth's thermal profile. Water Resour. Res., $1: 325-328$.

Bullard, E.C., 1939. Heat flow in South Africa. Proc. R. Soc. London A, 173:474-502.

Davis, E.E., Becker, K., Pettigrew, T., Carson, B., and MacDonald, R., 1992. CORK: a hydrologic seal and downhole observatory for deep-ocean boreholes. In Davis, E.E., Mottl, M.J., Fisher, A.T., et al., Proc. ODP, Init. Repts., 139: College Station, TX (Ocean Drilling Program), 43-53.

Fisher, A.T., and Hounslow, M.W., 1990. Transient fluid flow through the toe of the Barbados accretionary complex: constraints from Ocean Drilling Program Leg 110 heat flow studies and simple models. J. Geophys. Res., 95:8845-8858.

Foucher, J.-P., Le Pichon, X., Lallemant, S., Hobart, M.A., Henry, P., Benedetti, M., Westbrook, G.K., and Langseth, M.G., 1990. Heat flow, tectonics, and fluid circulation at the toe of the Barbados Ridge accretionary prism. J. Geophys. Res., 95:8859-8868.

Henry, P., Le Pichon, X., Lallemant, S., Lance, S., Martin, J., Foucher, J.P., Fiala-Medioni, A., Guilhaumou, N., Rostek, F., Pranal, V., and Castrec, M., 1996. Fluid flow in and around of a mud volcano field seaward of the Barbados accretionary wedge: Results from the Manon cruise. J. Geophys. Res., 101:20297-20323.

Hubbert, M.K., and Rubey, W.W., 1959. Role of fluid pressure in mechanicas of overthrust faulting, Part 1. Mechanics of fluid-filled porous solids and its application to overthrust faulting. Geol. Soc. Am. Bull., 70:115-166.

Kastner, M., Elderfield, H., and Martin, J.B., 1991. Fluids in convergent margins: what do we know about their composition, origin, role in diagenesis and importance for oceanic chemical fluxes? Philos. Trans. R. Soc. London A, 335:243-259.
Langseth, M.G., Westbrook, G.K., and Hobart, M.A., 1988. Geophysical survey of a mud volcano seaward of the Barbados Ridge accretionary complex. J. Geophys. Res., 93:1049-1061.

Le Pichon, X., Henry, P., and Lallemant, S., 1990. Water flow in the Barbados accretionary complex. J. Geophys. Res., 95:8945-8967. 1993. Annu. Rev. Earth Planet. Sci., 21:307-331.

Moore, J.C., and Vrolijk, P., 1992. Fluids in accretionary prisms. Rev. Geophys., 30:113-135.

Moore, J.C., Shipley, T.H., Goldberg, D., Ogawa, Y., Filice, F., Fisher, A., Jurado, M.-J., Moore, G.F., Raabute, A., Yin, H., Zwart, G., and Brückmann, W., 1995. Abnormal fluid pressure and fault zone dilation in the Barbados accretionary prism: evidence from logging while drilling. Geology, 23:605-608.

Screaton, E.J., Carson, B., and Lennon, G.P., 1995. Hydrogeologic properties of a thrust fault within the Oregon accretionary prism. J. Geophys. Res., 100:20025-20036.

Shipboard Scientific Party, 1988. Site 671. In Mascle, A., Moore, J.C., et al., Proc. ODP, Init. Repts., 110: College Station, TX (Ocean Drilling Program), 67-204.

Shipboard Scientific Party, 1995. Site 948. In Shipley, T.H., Ogawa, Y., Blum, P., et al., Proc. ODP, Init. Repts., 156: College Station, TX (Ocean Drilling Program), 87-192.

Shipley, T.H., Moore, G.F., Bangs, N.L., Moore, J.C., and Stoffa, P.L., 1994 Seismically inferred dilatancy distribution, northern Barbados Ridge décollement: implications for fluid migration and fault strength. Geology, 22:411-414.

von Huene, R., and Lee, H.J., 1983. The possible significance of pore fluid pressures in subduction zones. In Watkins, J.S., and Drake, C.L. (Eds.), Studies in Continental Margin Geology. AAPG Mem., 34:781-789.

Westbrook, G.K., 1991. Geophysical evidence for the role of fluids in accretionary wedge tectonics. Philos. Trans. R. Soc. London A, 335:227-242.

Date of initial receipt: 1 August 1996 Date of acceptance: 23 January 1997 Ms 156SR-045 


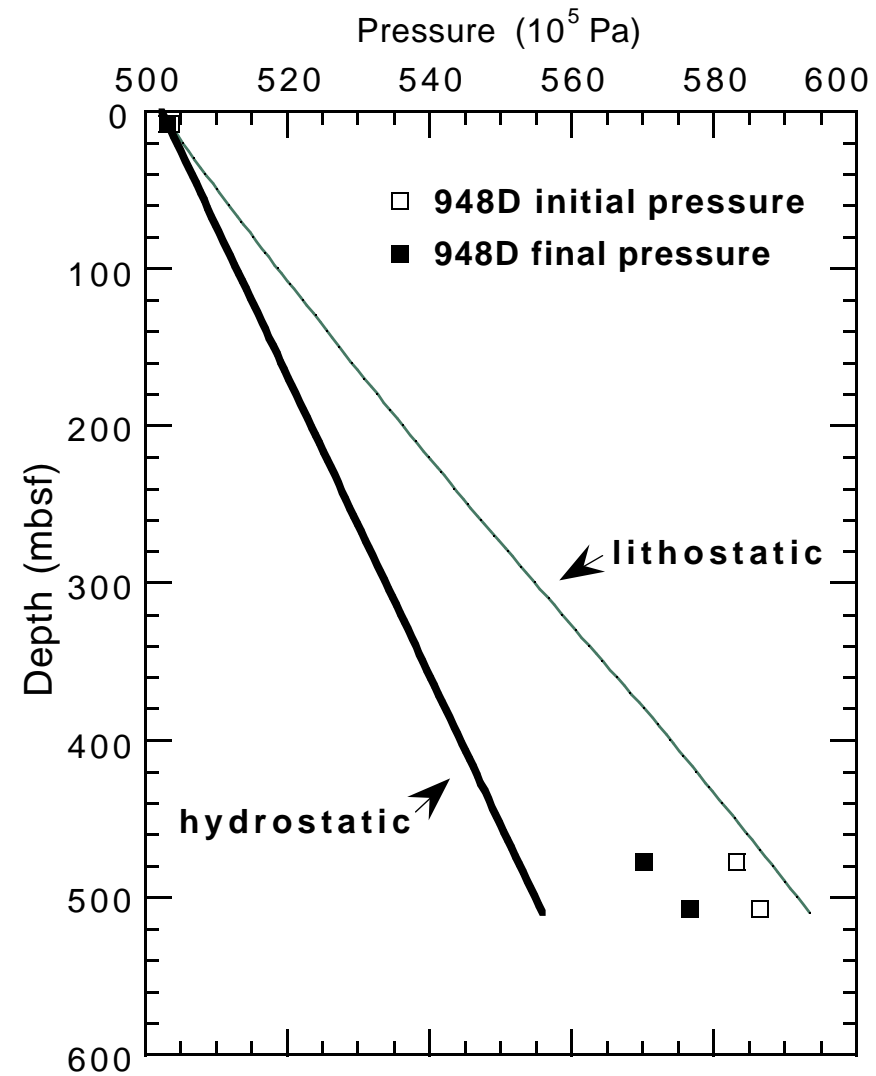

Figure 7. Initial (June 1994) and final (December 1995) borehole pressures measured in Hole 948D. 